\title{
PENGARUH DANA INVESTASI MELALUI INSTRUMEN SUN DAN SBSN TERHADAP PERTUMBUHAN EKONOMI INDONESIA
}

\author{
Tya Ryandini ${ }^{1}$
}

\begin{abstract}
The Influence of Investment Fund Through National Bond (SUN) and National Sukuk (SBSN) To Economic Growth in Indonesia. The aims of this research is to analyze the short term and long term influence of investment fund through National Bond (SUN) and National Sukuk (SBSN) to economic growth in Indonesia in the year of 2008 - 2012.The methode which used in this research is Error Correction Model. The result shows that economic development is positively influenced by National Bond in short term and long term. But, it negatively influenced by the National Sukuk both in short term and long term.
\end{abstract}

Keywords: National Bond, National Sukuk, Economic Growth of Indonesia, Error Correction Model.

Abstrak. Pengaruh Dana Investasi Melalui Instrumen SUN dan SBSN Terhadap Pertumbuhan Ekonomi Indonesia. Penelitian ini bertujuan untuk menganalisis pengaruh dana investasi melalui instrumen Surat Utang Negara (SUN) dan Surat Berharga Syariah Negara (SBSN) terhadap Pertumbuhan Ekonomi di Indonesia Periode 2008-2012 dalam jangka pendek maupun jangka panjang. Metode yang digunakan dalam penelitian ini adalah Error Correction Model (ECM). Hasil analisis menunjukkan bahwa variabel Surat Utang Negara (SUN) berpengaruh positif terhadap Pertumbuhan Ekonomi Indonesia dalam jangka pendek maupun jangka panjang. Sedangkan variabel Surat Berharga Syariah Negara (SBSN) memiliki pengaruh negatif terhadap Pertumbuhan Ekonomi Indonesia dalam jangka pendek maupun jangka panjang.

Kata Kunci: Surat Utang Negara (SUN), Surat Berharga Syariah Negara (SBSN), Pertumbuhan Ekonomi Indonesia (PDB), Error Correction Model (ECM)

\footnotetext{
${ }^{1}$ Naskah diterima: 12 Oktober 2013, direvisi: 12 Nopember 2013, disetujui: 20 Nopember 2013 DPP Ikatan Ahli Ekonomi Islam Indonesia (IAEI), JL. Dr. Wahidin No. 1, Senen, Jakarta Pusat. Email: tyaryandini@yahoo.com
} 


\section{PENDAHULUAN}

Dalam suatu perekonomian, pemerintah memiliki peran yang sangat penting. Beberapa tujuan penting dari kegiatan pemerintah adalah mengatasi masalah pengangguran, menghindari inflasi, dan mempercepat pembangunan ekonomi dalam jangka panjang. Usaha seperti itu membutuhkan banyak uang, dan pendapatan dari pajak saja tidak cukup untuk membiayainya. Maka, untuk memperoleh dana yang diperlukan, pemerintah dapat meminjam atau mencetak uang (Sukirno, 2004). Pertumbuhan ekonomi akan menjadi lebih pesat salah satunya dengan meningkatkan efisiensi penanaman modal (investasi) yang dijalankan. Pertumbuhan ekonomi suatu negara baru dimungkinkan jika investasi neto lebih besar daripada nol (Rahardja dan Manurung, 2008). Peningkatan investasi akan memberikan dampak signifikan bagi perkembangan dan pertumbuhan ekonomi negara (Subagyo, 2007).

Dalam rangka meningkatkan nilai investasi di Indonesia, pada umumnya pemerintah akan mengeluarkan berbagai instrumen atau surat berharga. Instrumen tersebut akan membantu pemerintah dalam membiayai pembangunan negara melalui APBN. Dalam UU No. 22 Tahun 2011 tentang APBN tahun 2012, APBN dipergunakan sebesar-besarnya untuk kesejahteraan rakyat. Sejalan dengan itu, belanja negara tahun 2012 sebesar Rp 1.435,4 triliun terdiri dari belanja pusat sebesar Rp 965 triliun dan belanja daerah sebesar Rp 470,4 triliun. Penerbitan SBN pada tahun 2012 meningkat dari tahun sebelumnya menjadi sebesar Rp 270.419 miliar. Kebijakan investasi yang dilakukan pemerintah untuk mendukung pertumbuhan ekonomi berupa penerbitan Surat Berharga Negara terdiri dari penerbitan Surat Utang Negara (SUN) dan Surat Berharga Syariah Negara (SBSN).

Berdasarkan Laporan Pertanggungjawaban Pengelolaan SBN Tahun 2011 yang diterbitkan Direktorat Jenderal Pengelolaan Utang Kementerian Keuangan, total nilai net nominal ON yang diterbitkan pada tahun 2011 sebesar Rp 110,514 triliun. Di samping menerbitkan ON dalam denominasi Rupiah, pemerintah Indonesia juga melakukan penerbitan International Bonds dengan total dana mencapai US\$ 2,5 miliar atau setara dengan Rp 21,44 triliun. Kebijakan investasi yang dapat dilakukan pemerintah selain menerbitkan Surat Perbendaharaan Negara (SPN) dan Obligasi Negara ialah dengan menerbitkan Surat Berharga Syariah Negara (SBSN). Seiring dengan sosialisasi di beberapa wilayah Indonesia, persentase peningkatan sukuk cukup pesat yakni 15 persen per tahun 2011. Peningkatan sukuk negara pada tahun 2011 diperkirakan mencapai sekitar Rp 38 Triliun (Hasan, 2012).

Di tengah kondisi perekonomian dunia yang melambat, pertumbuhan ekonomi Indonesia cenderung stabil. Berdasarkan data World Economic Outlook yang dirilis oleh International Monetary Fund (IMF) pada Oktober 2012, pertumbuhan ekonomi dunia dinilai mencapai 3,3 persen. Pada tahun yang sama, berdasarkan data Badan Pusat Statistik (BPS), perekonomian Indonesia mengalami pertumbuhan sebesar 6,3 persen. Menurut Menteri Keuangan RI Agus Martowardojo, hal ini menjadikan Indonesia menempati posisi sebagai negara dengan perekonomian terbaik kedua di dunia setelah China yang mencapai pertumbuhan ekonomi sebesar 7,8 persen. (Jawa Pos National Network, 2013)

Berdasarkan pemaparan tentang meningkatnya penghimpunan dana investasi dalam bentuk Surat Utang Negara (SUN) dan Surat Berharga Syariah 
Negara (SBSN) serta pertumbuhan ekonomi Indonesia yang dinilai stabil, peneliti tertarik untuk mengadakan penelitian yang membahas tentang "Pengaruh Dana Investasi Melalui Instrumen SUN dan SBSN terhadap Pertumbuhan Ekonomi Indonesia".

\section{TINJAUAN PUSTAKA}

Pertumbuhan ekonomi merupakan perubahan kondisi perekonomian suatu negara secara berkesinambungan menuju keadaan yang lebih baik selama periode tertentu. Pertumbuhan ekonomi dapat diartikan juga sebagai proses kenaikan kapasitas produksi suatu perekonomian yang diwujudkan dalam bentuk kenaikan pendapatan nasional. Adanya pertumbuhan ekonomi merupakan indikasi keberhasilan pembangunan ekonomi.

Infrastruktur, barang-barang modal dan kemajuan teknologi dalam suatu negara menjadi salah satu faktor penunjang bagi tumbuhnya perekonomian. Dalam rangka memenuhi kebutuhan akan faktor penunjang, pemerintah tentu membutuhkan dana yang tidak sedikit. Dana tersebut dapat diraih pemerintah dengan kegiatan penghimpunan dana investasi melalui instrumen pembiayaan seperti Surat Utang Negara (SUN) maupun Surat Berharga Syariah Negara (SBSN).

Surat Utang Negara (SUN) diterbitkan dengan tujuan untuk membiayai defisit APBN. Dana yang berhasil dihimpun dari penerbitan SUN akan mempengaruhi belanja pemerintah dalam menyediakan infrastruktur dan barang modal sehingga mampu meningkatkan produktivitas perekonomian. Surat Utang Negara (SUN) terdiri dari Surat Perbendaharaan Negara (SPN) dan Obligasi Negara. SPN berjangka waktu sampai dengan 12 bulan dengan pembayaran bunga secara diskonto, sedangkan Obligasi Negara berjangka waktu lebih dari 12 bulan dengan kupon dan/atau pembayaran bunga secara diskonto.

Tujuan penerbitan Surat Berharga Syariah Negara salah satunya ialah untuk membiayai proyek yang diselenggarakan pemerintah. Berbeda dengan SUN, pada SBSN terdapat underlying asset yang dapat dijadikan jaminan. Pada pelaksanaannya, SBSN yang sering juga disebut dengan Sukuk Negara menggunakan beberapa akad yang sesuai dengan syariah, seperti mudharabah, musyarakah, murabahah, salam, istishna' dan ijarah. Dengan tambahan danayang berasal dari instrumen SBSN, pemerintah mampu menambah modal yang digunakan untuk mendanai proyek tertentu sehingga dapat berpengaruh pada pertumbuhan ekonomi.

\section{METODE}

Dalam penelitian ini, teknik analisis data yang digunakan adalah analisis model koreksi kesalahan (Error Correction Model). Salah satu asumsi dalam analisis statistika adalah data berdistribusi normal. Eviews menggunakan dua cara untuk mengetahui apakah data berdistribusi normal, yakni dengan histogram dan uji Jarque - Bera.

Uji Linieritas adalah pengujian yang dilakukan untuk melihat apakah spesifikasi model yang digunakan sudah benar atau tidak. Untuk mendeteksi penghapusan variabel-variabel dan atau pilihan bentuk fungsional yang tak cocok, Ramsey telah mengembangkan sebuah uji umum untuk kesalahan spesifikasi model (Gujarari, 2007). Sebelum melakukan analisis, harus diketahui terlebih dahulu apakah data runtut waktu yang digunakan sudah stasioner. Untuk menguji stasioneritas data, dapat digunakan uji akar unit (Unit Root Test) yang 
dikembangkan oleh Dickey-Fuller. Dalam penelitian ini, pengujian data dilakukan dengan uji Augmented Dickey-Fuller.

Data yang tidak stasioner bila diregresi akan mudah menyebabkan regresi lancung. Data dikatakan stasioner bila memenuhi syarat berikut: pertama, ratarata dan variannya konstan sepanjang waktu; Kedua, kovarian antara dua data runtut waktu tergantung pada kelambanan antara dua periode tersebut. Oleh karenanya, data yang tidak stasioner harus distasionerkan terlebih dahulu (Winarno, 2009). Uji derajat integrasi juga dilakukan dengan menggunakan Uji Augmented Dickey-Fuller. Selanjutnya dilakukan uji kointegrasi. Terdapat tiga cara untuk menguji kointegrasi, yaitu: pertama, uji kointegrasi Engle-Granger (EG), kedua, uji Cointegrating Regression Durbin Watson (CRDW), dan ketiga, uji Johansen (Winarno, 2009). Pada penelitian ini, uji kointegrasi dilakukan dengan uji Johansen.

Uji asumsi klasik dilakukan untuk mengetahui apakah model estimasi telah memenuhi kriteria ekonometrika, dalam arti tidak terjadi penyimpangan yang cukup serius dari asumsi-asumsi yang harus dipenuhi dalam metode Ordinary Least Square (OLS). Dalam regresi linear berganda akan dijumpai berbagai permasalahan, seperti multikolinieritas, heteroskedastisitas, dan autokorelasi (Nachrowi dan Usman, 2008). Uji asumsi klasik dilakukan untuk melihat apakah terdapat permasalahan tersebut dalam model regresi linier ganda, sehingga model tersebut memenuhi kriteria BLUE (Best Linier Unbiased Estimator).

Penelitian dengan ECM ini digunakan untuk melihat pengaruh jangka pendek dan jangka panjang antara variabel independen terhadap variabel dependen. Hubungan pertumbuhan ekonomi dan faktor-faktor yang mempengaruhi dapat diformulasikan sebagai berikut:

$$
\begin{aligned}
& \mathrm{PDB}_{\mathrm{t}}=\mathrm{f}\left(\mathrm{SUN}_{\mathrm{t}}, \mathrm{SBSN}_{\mathrm{t}}\right) \\
& \text { Model ECM pada penelitian ini ialah sebagai berikut: } \\
& \operatorname{DLnPDB}_{\mathrm{t}}=\beta_{0}+\beta_{1} \operatorname{DLnSUN}_{\mathrm{t}}+\beta_{2} \operatorname{DLnSBSN}_{\mathrm{t}}+\beta_{3} \operatorname{LnSUN}_{\mathrm{t}-1}+ \\
& \beta_{4} \operatorname{LnSBSN}_{\mathrm{t}-1}+\beta_{5} \text { ECT } \\
& \text { Dengan: } \\
& \beta_{0} \quad=\text { Konstanta } \\
& \beta_{1}-\beta_{4}=\text { Koefisien Regresi } \\
& \beta_{5} \quad=\text { Koefisien ECT } \\
& \text { DLnPDB }_{\mathrm{t}} \quad=\text { Perubahan PDB periode } \mathrm{t} \\
& \text { DLnSUN }_{\mathrm{t}} \quad=\text { Total Penghimpunan Dana Investasi SUN (jangka pendek) } \\
& \text { DLnSBSN }_{\mathrm{t}}=\text { Total Penghimpunan Dana Investasi SBSN (jangka pendek) } \\
& \text { LnSUN }_{\mathrm{t}-1}=\text { Total Penghimpunan Dana Investasi SUN (jangka panjang) } \\
& \text { LnSBSN }_{\mathrm{t}-1}=\text { Total Penghimpunan Dana Investasi SBSN (jangka } \\
& \text { panjang) } \\
& \text { ECT = Error Correction Term }
\end{aligned}
$$

\section{PEMBAHASAN}

Utang merupakan bagian dari kebijakan fiskal dalam perekonomian yang bertujuan untuk memberikan kemakmuran dan menciptakan kenyamanan serta keamanan bagi penduduk suatu negara.Berdasarkan data dari Government Debt Profile edisi April 2013 yang diterbitkan oleh Direktorat Jenderal Pengelolaan Utang Kementerian Keuangan, nominal utang pemerintah meningkat dari Rp 1.636,74 triliun pada tahun 2008 menjadi Rp 1.975,42 triliun pada tahun 2012. 
Total utang pemerintah didominasi oleh diterbitkannya Surat Berharga Negara (SBN) yang dananya berasal dari masyarakat

Tabel 1 PerkembanganUtangPemerintah

\begin{tabular}{|c|c|c|c|c|c|c|c|c|c|c|}
\hline & \multicolumn{2}{|c|}{2008} & \multicolumn{2}{|c|}{2009} & \multicolumn{2}{|c|}{2010} & \multicolumn{2}{|c|}{2011} & \multicolumn{2}{|c|}{2012} \\
\hline & Outs & $\%$ & Outs & $\%$ & Outs & $\%$ & Outs & $\%$ & Outs & $\%$ \\
\hline SBN & 906.50 & 55 & 979.46 & 62 & 1064.41 & 63 & 1187.66 & 66 & 1361.10 & 69 \\
\hline $\begin{array}{l}\text { Denominasi } \\
\text { Rupiah }\end{array}$ & 783.86 & & 836.31 & & 902.43 & & 992.03 & & 1096.19 & \\
\hline $\begin{array}{l}\text { Denominasi } \\
\text { Valas }\end{array}$ & 122.64 & & 143.15 & & 161.98 & & 195.63 & & 264.91 & \\
\hline Pinjaman & 730.25 & 45 & 611.20 & 38 & 617.25 & 37 & 621.29 & 34 & 614.32 & 31 \\
\hline $\begin{array}{l}\text { Denominasi } \\
\text { Rupiah }\end{array}$ & 0.00 & & 0.00 & & 0.39 & & 1.01 & & 1.80 & \\
\hline $\begin{array}{l}\text { Denominasi } \\
\text { Valas }\end{array}$ & 730.25 & & 611.20 & & 616.86 & & 620.28 & & 612.52 & \\
\hline TotalUtang & 1636.74 & 100 & 1590.66 & 100 & 1681.66 & 100 & 1808.95 & 100 & 1975.42 & 100 \\
\hline
\end{tabular}

Dalam rangka perluasan basis investor, diversifikasi sumber pembiayaan, dan pengembangan pasar keuangan dalam negeri, Pemerintah telah menerbitkan surat berharga berdasarkan prinsip syariah, atau dikenal secara internasional dengan istilah sukuk. Instrumen keuangan ini memiliki perbedaan pokok antara lain berupa penggunaan konsep imbalan dan bagi hasil sebagai pengganti bunga, adanya suatu transaksi pendukung (underlying transaction) berupa sejumlah tertentu aset yang menjadi dasar penerbitan sukuk, serta adanya aqad atau perjanjian antara para pihak yang disusun berdasarkan prinsip-prinsip syariah.

Berdasarkan data yang dihimpun, terlihat bahwa pada awal tahun penerbitannya (2008), SBSN di Indonesia mampu menghimpun dana investasi sebesar Rp 4.699.700.000.000. Penghimpunan dana investasi melalui penerbitan SBSN mengalami kenaikan setiap tahunnya hingga mencapai Rp 57.088.810.000.000,- pada tahun 2012.

Suatu perekonomian dikatakan mengalami pertumbuhan ekonomi jika jumlah produksi barang dan jasanya meningkat. Pertumbuhan ekonomi mengindikasikan bahwa suatu perekonomian memiliki faktor-faktor produksi yang bertambah, baik dalam jumlah maupun kualitasnya.Untuk mengukur pertumbuhan ekonomi suatu negara dari tahun ke tahun, nilai PDB yang digunakan adalah PDB berdasarkan harga konstan.

Angka PDB tertinggi terjadi pada kuartal ketiga tahun 2012 sebesar Rp 671.780.800.000.000,-. Pertumbuhan ekonomi dunia pada tahun 2012 cenderung terus menurun dengan mencatat pertumbuhan sebesar 3,3\% dibandingkan 
dengan tahun sebelumnya sebesar 3,9\%. Perekonomian Indonesia pada tahun 2012 masih tumbuh cukup baik sebesar 6,23\% meskipun masih lebih rendah dari tahun sebelumnya yakni 6,49\%. Pertumbuhan ekonomi terutama masih ditopang oleh kuatnya konsumsi domestik, khususnya konsumsi rumah tangga dan investasi.

Berikut adalah model persamaan ECM yang digunakan dalam penelitian ini: $\operatorname{DLnPDB}_{\mathrm{t}}=\beta_{0}+\beta_{1} \operatorname{DLnSUN}_{\mathrm{t}}+\beta_{2} \operatorname{DLnSBSN}_{\mathrm{t}}+\beta_{3} \operatorname{LnSUN}_{\mathrm{t}-1}+$ $\beta_{4} \mathrm{LnSBSN}_{\mathrm{t}-1}+\beta_{5} \mathrm{ECT}$

Hasil pengolahan data regresi linier ECM tersebut dengan menggunakan pengolah data Eviews 6.0 adalah sebagai berikut:

Tabel 2. Uji Error Correction Model (ECM)

\begin{tabular}{crlrr}
\hline \hline \multicolumn{1}{c}{ Variable } & Coefficient & Std. Error & t-Statistic & Prob. \\
\hline \hline C & -0.965691 & 0.403880 & -2.391034 & 0.0405 \\
D(LNSUN) & 0.033264 & 0.011361 & 2.927982 & 0.0168 \\
D(LNSBSN) & -0.008050 & 0.003378 & -2.382816 & 0.0410 \\
LNSUN(-1) & 0.033344 & 0.016869 & 1.976605 & 0.0795 \\
LNSBSN(-1) & -0.002109 & 0.006032 & -0.349690 & 0.7346 \\
RESID01(-1) & -0.111131 & 0.046250 & -2.402834 & 0.0397 \\
\hline \hline R-squared & 0.808943 & Mean dependent var & 0.015072 \\
Adj R-squared & 0.702801 & S.D. dependent var & 0.020884 \\
S.E. of regression & 0.011385 & Akaike info criterion & -5.823822 \\
Sum squared resid & 0.001167 & Schwarz criterion & -5.540602 \\
Log likelihood & 49.67866 & Hannan-Quinn criter. & -5.826838 \\
F-statistic & 7.621289 & Durbin-Watson stat & 3.235884 \\
Prob(F-statistic) & 0.004672 & & & \\
\hline \hline
\end{tabular}

Pada pengujian kointegrasi yang telah dilakukan, ditemukan bahwa data dalam penelitian ini memiliki hubungan keseimbangan jangka panjang antara variabel independen dengan variabel dependen. Walaupun terdapat keseimbangan jangka panjang, dalam jangka pendek mungkin saja terjadi ketidakseimbangan. Untuk menguji apakah variabel-variabel memiliki pengaruh dalam jangka pendek, maka dilakukan analisis dengan pendekatan Error Correction Model.

Untuk menyatakan apakah model yang digunakan benar atau tidak, maka koefisien Error Correction Term harus signifikan. Nilai koefisien ECT pada tabel dapat dilihat pada nilai resid01(-1) sebesar 0,111131 yang berarti bahwa ketidaksesuaian pertumbuhan PDB aktual dengan PDB potensial akan dieliminasi atau dihilangkan dalam suatu periode penelitian sebesar 11,11\%. Dapat dilihat bahwa nilai t-Statistic cukup tinggi yakni 2,402834 yang lebih tinggi dari 2 dan nilai probabilitas ECT sebesar 0,0397 yang lebih kecil dari 0,05. Hal ini berarti ECT sudah signifikan pada tingkat kepercayaan $\alpha=5 \%$ dan menunjukkan bahwa model dari pengujian ECM ini sudah valid. 
Tabel 3 Koefisien ECM

\begin{tabular}{ccc}
\hline \multirow{2}{*}{ Variabel } & \multicolumn{2}{c}{ Coefficient } \\
\cline { 2 - 3 } & Jangka Pendek & Jangka Panjang \\
\hline $\begin{array}{c}\text { Konstanta } \\
\text { Surat Utang Negara } \\
\text { (SUN) } \\
\begin{array}{c}\text { Surat Berharga Syariah } \\
\text { Negara (SBSN) }\end{array}\end{array}$ & $-0,965691$ & $-0,965691$ \\
\hline
\end{tabular}

Berdasarkan tabel 3, maka hasil regresi ECM dalam jangka pendek dan jangka panjang ialah sebagai berikut:

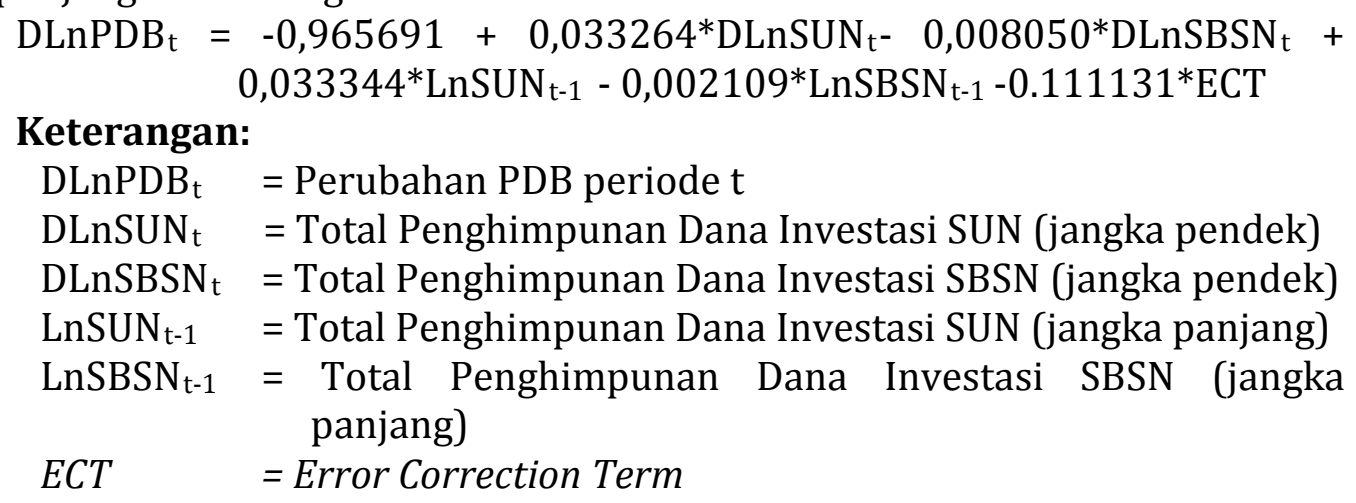

Berdasarkan hasil di atas, dapat dilihat dari sisi kontanta, bahwa dalam jangka pendek maupun jangka panjang, nilai konstanta $(-0,965691)$ menunjukkan apabila nilai variabel independen konstan, maka besarnya penerimaan PDB turun sebesar 0,96 persen.

Pengaruh Dana Investasi Melalui Instrumen Surat Utang Negara (SUN) terhadap Produk Domestik Bruto (PDB) dapat dilihat secara jangka pendek maupun jangka panjang. Pertama, secara jangka pendek, DLnSUN menunjukkan nilai probabilitasnya sebesar 0,0168 yang lebih kecil dari 0,05. Hal ini menunjukkan bahwa variabel SUN memiliki hubungan yang signifikan pada tingkat kepercayaan $\alpha=0,05$ pada jangka pendek sebesar 0,033264 . Realisasi penghimpunan dana dari penerbitan SUN berpengaruh signifikan dalam jangka pendek terhadap Pertumbuhan Ekonomi. Hal ini sesuai dengan penelitian yang dilakukan oleh Adrian Sutawijaya dan Zulfahmi bahwa investasi memiliki pengaruh yang signifikan terhadap pertumbuhan ekonomi. Peningkatan investasi akan meningkatkan kapasitas produksi yang pada akhirnya berujung pada pembukaan lapangan kerja baru yang pada tahap selanjutnya akan mendorong pertumbuhan ekonomi.

Kedua, secara jangka panjang, Pada LnSUN(-1) nilai koefisiennya sebesar 0,033344 dan memiliki probabilitas sebesar 0,0795 yang lebih besar dari 0,05 . Hal ini menunjukkan bahwa variabel SUN memiliki pengaruh positif yang tidak signifikan pada tingkat kepercayaan $\alpha=0,05$. Dapat diartikan bahwa dalam jangka 
panjang, realisasi penerbitan SUN tidak berpengaruh secara signifikan terhadap Pertumbuhan Ekonomi Indonesia.

Pengaruh Dana Investasi Melalui Instrumen Surat Berharga Syariah Negara (SBSN) terhadap Produk Domestik Bruto (PDB) dapat dilihat secara jangka pendek dan jangka panjang. Dalam jangka pendek, dari tabel terlihat bahwa DLnSBSN memiliki nilai koefisien sebesar $(-0,008050)$ dengan probabilitas 0.0410 yang lebih kecil dari 0,05. Hal ini mengindikasikan bahwa penghimpunan dana investasi melalui penerbitan SBSN memiliki pengaruh negatif yang signifikan terhadap Pertumbuhan Ekonomi dalam jangka pendek pada tingkat kepercayaan $\alpha=0,05$. Jika jumlah dana hasil penerbitan SBSN naik sebesar 1\%, maka pertumbuhan ekonomi akan mengalami penurunan sebesar 0,04 persen. Secara jangka panjang, LnSBSN(-1) memiliki nilai koefisien sebesar $(-0,002109)$ dan nilai probabilitasnya sebesar 0,7346, lebih besar dari 0,05. Pada jangka panjang, dana yang dihasilkan dari realisasi penerbitan SBSN memiliki pengaruh negatif yang tidak signifikan terhadap Pertumbuhan Ekonomi. Sehingga berapapun kenaikan penghimpunan dana investasi dari penerbitan SBSN, tidak akan mempengaruhi pertumbuhan ekonomi secara signifikan.

Error Correction Model dalam tabel memperlihatkan nilai Adjusted RSquared sebesar 0,702801 yang berarti 70\% variabel dependen (pertumbuhan ekonomi) dapat dijelaskan oleh variabel independen (Realisasi Penerbitan Surat Utang Negara dan Surat Berharga Syariah Negara). Sisanya sebesar 30\% dijelaskan oleh variabel lain yang tidak termasuk dalam model penelitian ini. Nilai t-Statistic ECT pada model tersebut sebesar 2,402834 yang lebih tinggi dari 2 dan nilai probabilitas ECT sebesar 0,0397 yang lebih kecil dari 0,05 menunjukkan bahwa model dari pengujian ECM ini sudah valid.

Dalam penelitian ini dihasilkan bahwa realisasi penerbitan SUN memiliki pengaruh yang signifikan untuk jangka pendek, namun tidak berpengaruh secara signifikan dalam jangka panjang. Dalam jangka pendek, variabel SUN memiliki pengaruh yang signifikan sebesar 0,033264 terhadap PDB. Hal ini mengindikasikan ketika jumlah dana realisasi penerbitan SUN naik sebesar 1\%, maka pertumbuhan ekonomi akan naik sebesar 0,033 persen.

Seperti telah dipaparkan sebelumnya bahwa utang dilakukan pemerintah untuk membiayai defisit APBN, pembiayaan arus kas jangka pendek, dan refinancing utang lama. Pada tahun 2012, Indonesia mengalami defisit APBN yang tinggi karena besarnya subsidi BBM dan sumber daya energi yang diberikan pemerintah yakni sebesar Rp 241,5 Triliun. Pemerintah menganggap bahwa subsidi BBM tidak tepat pada sasaran dan menjadi hal yang memberatkan karena menghambat program peningkatan kesejahteraan masyarakat. Pengalokasian dana untuk menutup biaya defisit ini menjadikan pembangunan infrastruktur menjadi sangat terbatas. Padahal, yang menjadi tujuan utama pemerintah dalam melakukan kebijakan utang adalah untuk pembangunan infrastruktur yang diharapkan berimbas pada pertumbuhan ekonomi Indonesia untuk jangka panjang.

Pada penelitian mengenai SBSN, realisasi penghimpunan dana investasi SBSN memiliki pengaruh negatif yang signifikan terhadap pertumbuhan ekonomi dalam jangka pendek, namun tidak berpengaruh signifikan dalam jangka panjang. Pengaruh negatif ini bertentangan dengan teori maupun pendapat yang 
mengemukakan bahwa investasi dapat menjadi pendorong pertumbuhan ekonomi suatu negara. Dengan pengaruh yang negatif antara realisasi penghimpunan dana investasi melalui instrumen SBSN dengan pertumbuhan ekonomi mengindikasikan bahwa belum terserapnya dengan baik dana tersebut. Tidak signifikannya pengaruh penghimpunan dana melalui instrumen SBSN ini disebabkan masih terlalu kecilnya jumlah dana yang berhasil dihimpun jika dibandingkan dengan Surat Utang Negara (SUN).

\section{SIMPULAN}

Utang merupakan bagian yang tidak terpisahkan dalam pelaksanaan kebijakan yang diperlukan untuk membiayai defisit APBN, penyediaan arus kas jangka pendek, dan refinancing utang lama. Pemerintah juga telah menerbitkan surat berharga berdasarkan prinsip syariah, atau dikenal secara internasional dengan istilah sukuk (Surat Berharga Syariah Negara). Data dari tahun ke tahun menunjukkan bahwa penghimpunan dana investasi melalui instrumen SUN dan SBSN telah mengalami peningkatan.

Pada jangka pendek, pengaruh dana investasi melalui instrumen SUN ialah sebesar 0,033264 dan pada jangka panjang pengaruhnya ialah sebesar 0,033344. Instrumen SBSN memiliki pengaruh negatif dalam jangka pendek maupun jangka panjang. Dalam jangka pendek, pengaruhnya ialah sebesar $(-0,008050)$ dan pada jangka panjang, pengaruhnya ialah sebesar (-0,002109).

DLnSUN menunjukkan nilai probabilitasnya sebesar 0,0168 yang lebih kecil dari 0,05. Hal ini menunjukkan bahwa variabel SUN memiliki hubungan yang signifikan pada tingkat kepercayaan $\alpha=0,05$ pada jangka pendek sebesar 0,033264. Dana investasi dari instrumen SUN berpengaruh signifikan dalam jangka pendek terhadap Pertumbuhan Ekonomi. LnSUN(-1) memiliki probabilitas sebesar 0,0795 yang lebih besar dari 0,05. Hal ini menunjukkan bahwa variabel SUN memiliki pengaruh positif yang tidak signifikan pada tingkat kepercayaan $\alpha=$ 0,05. Dapat diartikan bahwa dalam jangka panjang, dana investasi melalui instrumen SUNtidak berpengaruh secara signifikan terhadap Pertumbuhan Ekonomi Indonesia. Pada tabel terlihat bahwa DLnSBSN memiliki probabilitas 0.0410 yang lebih kecil dari 0,05. Hal ini mengindikasikan bahwa dana investasi melalui instrumen SBSN memiliki pengaruh negatif yang signifikan terhadap Pertumbuhan Ekonomi dalam jangka pendek pada tingkat kepercayaan $\alpha=0,05$. Jika jumlah dana hasil penerbitan SBSN naik sebesar 1\%, maka pertumbuhan ekonomi akan mengalami penurunan sebesar 0,04 persen.LnSBSN(-1) memiliki nilai probabilitas sebesar 0,7346 , lebih besar dari 0,05 . Pada jangka panjang, dana yang dihasilkan dari instrumen SBSN memiliki pengaruh negatif yang tidak signifikan terhadap Pertumbuhan Ekonomi. Sehingga berapapun kenaikan penghimpunan dana investasi dari instrumen SBSN, tidak akan mempengaruhi pertumbuhan ekonomi secara signifikan.

\section{PUSTAKA ACUAN}

Al Arif, M. N. R. 2010. Teori Makroekonomi Islam. Bandung: Alfabeta Anoraga, Pandji dan P. Piji. 2008. Pengantar Pasar Modal. Jakarta: Rineka Cipta Antonio, M. Syafi'i. 2001. Bank Syariah dari Teori ke Praktik. Jakarta: Gema Insani 
Arikunto, Suharsimi. 2010. Prosedur Penelitian: Suatu Pendekatan Praktik . Jakarta: Rineka Cipta

Asnuri, Wulan. 2012. "Pengaruh Total Pembiayaan Bank Syariah, Sertifikat Bank Indonesia Syariah, dan Kontribusi Ekspor terhadap Pertumbuhan Ekonomi Indonesia." Skripsi S1 Fakultas Syariah dan Hukum, Universitas Islam Negeri Syarif Hidayatullah Jakarta

Boediono dan W. Koster. 2008. Teori dan Aplikasi Statistika dan Probabilitas. Bandung: PT Remaja Rosdakarya

Case, Karl E. dan R. C. Fair. 2004. Prinsip-prinsip Ekonomi Makro. Jakarta: PT INDEKS, Kelompok Gramedia

Direktorat Pembiayaan Syariah, Direktorat Jenderal Pengelolaan Utang (DJPU), Departemen Keuangan RI. 2008. Mengenal Sukuk, Instrumen Investasi Berbasis Syariah. Jakarta: Direktorat Pembiayaan Syariah Departemen keuangan RI

Fatah, Dede Abdul. 2011. "Perkembangan Obligasi Syari'ah (Sukuk) di Indonesia: Analisis Peluang dan Tantangan." Innovatio Vol. X. No. 2 (Juli-Desember 2011): h. 281-301.

Government Debt Profile edisi April 2013

Gujarati, D. N. 2007. Dasar-dasar Ekonometrika. Jakarta: Penerbit Erlangga

Harahap, Sofyan S. 2008. "Sukuk Sebagai Instrumen Pendanaan Negara”. La Riba Vol. 2. No. 2 (Desember 2008): h. 217

Irwanto, Wien (Direktorat Pembiayaan Syariah, Ditjen Pengelolaan Utang Kemenkeu RI). 2012. "Pembiayaan Proyek Melalui Penerbitan SBSN/Sukuk Negara". Dalam Forum Riset Ekonomi dan Keuangan Syariah, 22 November 2012 di Pekanbaru Riau, h. 4.

Laporan Perekonomian Indonesia Tahun 2008

Laporan Pertanggungjawaban SBN 2011

Muhamad. 2008. Metodologi Penelitian Ekonomi Islam. Jakarta: Rajawali Pers

Mawaddah. 2012. "Analisis Pengaruh Jumlah Uang Beredar (JUB), Pembiayaan Mudharabah (PM) dan Kontribusi Pertumbuhan Zakat, Infak dan Sedekah (ZIS) terhadap Pertumbuhan Ekonomi di Indonesia Periode 2007-2010." Skripsi S1 Fakultas Ekonomi dan Bisnis, UIN Syarif Hidayatullah Jakarta

Nachrowi, N. D. dan Hardius Usman. 2008. Penggunaan Teknik Ekonometri. Jakarta: PT RajaGrafindo Persada

Nusantara, Agung dan E. P. Astutik. 2001. "Analisis Peranan Modal Asing terhadap Pertumbuhan Ekonomi Indonesia". Jurnal Bisnis dan Ekonomi

P3EI UII Yogya dan Bank Indonesia. 2009 Ekonomi Islam. Jakarta: Rajawali Pers

Peraturan Menteri Keuangan No. 08/PMK.08/2008 Tentang Penjualan Surat Utang Negara dengan Private Placement di Pasar Perdana Dalam Negeri.

Peraturan Menteri Keuangan No. 50/PMK.08/2008 Tentang Lelang Surat Utang Negara di Pasar Perdana.

Peraturan Menteri Keuangan No. 11/PMK.08/2009 Tentang Penerbitan dan Penjualan Surat Berharga Syariah Negara di Pasar Perdana dalam Negeri dengan Cara Lelang.

Peraturan Menteri Keuangan No. 199/PMK.08/2012 Tentang Penerbitan dan Penjualan Surat Berharga Syariah Negara dengan Cara Bookbuilding di Pasar Perdana dalam Negeri. 
Peraturan Menteri Keuangan No. 239/PMK.08/2012 Tentang Penerbitan dan Penjualan Surat Berharga Syariah Negara dengan Cara Penempatan Langsung (Private Placement).

Rahardja, Prathama dan M. Manurung. 2008. Teori Ekonomi Makro: Suatu Pengantar. Jakarta: Lembaga Penerbit FEUI

Rochaeti, Ety dkk. 2007. Metodologi Penelitian Bisnis dengan Aplikasi SPSS. Jakarta: Penerbit Mitra Wacana Media

Salim, Fahmi. 2011. "Konsep dan Aplikasi Sukuk dalam Kebijakan Fiskal di Indonesia." Skripsi S1 Fakultas Syariah dan Hukum Universitas Islam Negeri Syarif Hidayatullah Jakarta

Salvatore, Dominick. 2002. Managerial Economicsdalam Perekonomian Global. Jakarta: PT Penerbit Erlangga

Slavin, Stephen L. 2008. Macroeconomics. New York: The McGraw-Hill Companies

Subagyo, Ahmad. 2007. Studi Kelayakan. Jakarta: PT Elex Media Komputindo.

Sukirno, Sadono. 2004. Makroekonomi: Teori Pengantar, ed. III. Jakarta: PT Raja Grafindo Persada

---------------. 2000. Makroekonomi Modern: Perkembangan Pemikiran dari Klasik hingga Keynesian Baru. Jakarta: PT Raja Grafindo Persada.

Supranto, J. 2004. Ekonometri Buku Kedua. Jakarta: Penerbit Ghalia Indonesia.

Sutawijaya, Adrian dan Zulfahmi. 2010. "Pengaruh Ekspor dan Investasi terhadap Pertumbuhan Ekonomi Indonesia tahun 1980-2006". Jurnal Organisasi dan Manajemen Volume 6. No. 1, 2010.

Tim Penyusun Direktorat Pembiayaan Syariah. 2010. Tanya Jawab SBSN Edisi Kedua. Jakarta: Direktorat Pembiayaan Syariah Ditjen Pengelolaan Utang Kemenkeu RI

World Economic Outlook October 2012

Winarno, Wing W. 2009. Analisis Ekonometrika dan Statistika dengan Eviews ed. Kedua. Yogyakarta: Unit Penerbit dan Percetakan STIM YKPN. 